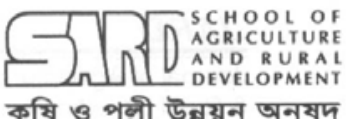

কৃষि ও পল्षी উन्नয়न অनूষদ
Available online at

http:/ / www.banglajol.info/index.php/jard
J ARD

Journal of Agriculture

\& Rural Development

\title{
Effects of Indigenous Mulches on Growth and Yield of Tomato
}

\author{
M. A. KAYUM ${ }^{1 *}$, M. AsAduzzaman ${ }^{2}$ \& M. Z. HAQUE ${ }^{1}$ \\ ${ }^{1}$ Department of Agricultural Botany, Patuakhali Science and Technology University, Dumki, \\ Patuakhali, Bangladesh \\ ${ }^{2}$ Former M.S. Student, Bangladesh Agricultural University, Mymensingh-2202, Bangladesh
}

\begin{abstract}
Three popular tomato varieties namely, Ratan, BARI tomato-3 and BARI tomato-6 were experimentally evaluated to identify the potential mulch on growth and yield, where the experiment consisted of four mulching treatments viz. water hyacinth, straw, am-ada leaf and banana leaf with a control (no mulch). The experiment was conducted under rainfed condition. In the experiment, mulching showed significant effect on growth, yield components and thus on the yield of tomato. Yield contributing characters were significantly higher when water hyacinth mulch was used. The variety Ratan produced the highest (53.74 tha) fruit yield, while BARI tomato-3 showed the lowest (48.89 t/ha) fruit yield. The combination of mulching and variety exhibited significant variation in some yield components and yield. The combination of water hyacinth and Ratan produced the maximum yield (62.16 t/ha) and thus the experiment revealed that water hyacinth and straw mulches have potentiality to increase the yield of tomato.
\end{abstract}

Key words: Indigenous mulch, growth, yield, tomato.

\section{INTRODUCTION}

Tomato (Lycopersicon esculentum Mill.) belongs to the family solanaceae. In Bangladesh, tomato is grown during the months from September to April, when rainfall is scarce, and soil moisture (250 $\mathrm{mm}$ ) is exhausted by evapotranspiration. Water is the single factor, which directly influence the yield of tomato. Successful tomato cultivation largely depends on the judicious application of manures and fertilizers, efficient use of available soil moisture, spacing, time of planting, weed control etc. Out of these factors, efficient use of soil moisture is very important. Rainfall is scanty during September to April in Bangladesh when growers have to depend either on natural precipitation or irrigation for tomato cultivation. Moreover, many of the farmers can not afford the expenses of irrigation. Under this situation indigenous mulching could be a good substitute for irrigation. Indigenous mulches like straw, rice husk, water hyacinth, crop residues are generally practiced in the production of horticultural crops. Different types of mulch play an important role in conserving soil moisture (Suh and Kim, 1991). Mulch regulates soil temperature, creates suitable condition for germination, improves soil moisture, suppresses weed growth, saves labour cost (Patil and Basad, 1972) and improves soil physical conditions by enhancing biological activity of soil fauna and thus increases soil fertility (Lal, 1989) which ultimately increases the yield of tomato. In addition, mulching has the unique character of reducing the maximum soil temperature and increasing the minimum temperature (Singh et al., 1987).

*Corresponding author: Lecturer, Department of Agricultural Botany, PSTU, Dumki, Patuakhali, E-mail: kayum_pabna @ yahoo.com

(C) 2008 School of Agriculture and Rural Development, Bangladesh Open University, All rights reserved. 


\section{MATERIALS AND METHODS}

An experiment was conducted at the field laboratory of the Department of Crop Botany, BAU, Mymensingh, during October 2002 to April 2003. The land was ploughed with power tiller. During land preparation, weeds and other stubbles of previous crop were collected and removed from the land. The climate of the area was subtropical, characterized by heavy rainfall, high humidity and high temperature during the months from April to September. Scanty rainfall associated with moderately low temperature, low humidity and short day during the rest period of the year. The experiment consisted of four types of mulches such as water hyacinth $\left(\mathrm{M}_{1}\right)$, straw $\left(\mathrm{M}_{2}\right)$, am-ada leaf $\left(\mathrm{M}_{3}\right)$ and Banana leaf $\left(\mathrm{M}_{4}\right)$ with a control (Mo) where no mulch was used. Three tomato varieties namely BARI tomato-3 $\left(\mathrm{V}_{1}\right)$, Ratan $\left(\mathrm{V}_{2}\right)$ and BARI tomato-6 $\left(V_{3}\right)$ were experimentally evaluated. The experiment was conducted in a Randomized Complete Block Design (RCBD) with three replications. The unit plot size was $1 \mathrm{~m} \times 1 \mathrm{~m}$.

Tomato seedlings were raised in a seedbed. The size of the seedbed was $3 \mathrm{~m} \times 1 \mathrm{~m}$. The seeds $(3 \mathrm{~g})$ of each variety were sown in the seedbed on $30^{\text {th }}$ October, 2002. After sowing, the seeds were covered with light soil. Complete germination of the seeds took place within 3 to 5 days of sowing the healthy and uniform of 25 days old from all varieties were transplanted separately. The seedbeds were watered before uprooting the seedlings in order to minimize the damage of the roots. The seedlings were watered after transplanting. Shading was provided using banana leaf sheath for three days to protect the seedlings from direct sunlight. The land was fertilized with $1 \mathrm{~kg}$ cow dung, $55 \mathrm{~g}$ urea, $45 \mathrm{~g}$ TSP and $25 \mathrm{~g}$ MP per plot. After transplanting four types of mulches, viz. water hyacinth $\left(M_{1}\right)$, straw $\left(M_{2}\right)$, am-ada leaf $\left(M_{3}\right)$ and banana leaf $\left(M_{4}\right)$ were placed on the respective plots according to the layout of the experiment. The fresh water hyacinth, banana leaf and am-ada leaf were dried in the sun for 7 days before placing on the plot. No irrigation was given to the experimental plots. The crop was grown under rainfed condition. After transplanting, different intercultural operations were accomplished for better growth and development of the plants. Plant height $(\mathrm{cm})$, number of leaves per plant, leaf area per plant $\left(\mathrm{cm}^{2}\right)$, dry weight of leaves, stem, roots and fruits per plant $(\mathrm{g})$, total dry matter $(\mathrm{g})$, number of flower clusters per plant, number of fruits per cluster, number of fruits per plant, weight of individual fruit $(\mathrm{g})$, weight of fruits per plant $(\mathrm{kg})$, weight of fruits per plot $(\mathrm{kg})$ and fruit yield $(\mathrm{t} / \mathrm{ha}$ ) were recorded up to maturity and tomato yield was assessed at the final harvest. Data were analyzed with MSTAT-C following the ANOVA and mean differences were adjudged by least significant difference (LSD) (Gomez and Gomez, 1984).

\section{RESULTS AND DISCUSSION}

Different indigenous mulches exhibited highly significant effect on plant height $(\mathrm{cm})$, number of leaves per plant, leaf area per plant $\left(\mathrm{cm}^{2}\right)$, dry weight of leaves, stem and roots and fruits per plant, at final harvest of tomato (Table 1). The tallest plant $(123.20 \mathrm{~cm}$ ), highest number of leaves $(65.73)$, greater leaf area $\left(1007.00 \mathrm{~cm}^{2}\right)$ and maximum dry weight of leaves, stem, roots and fruits per plant were obtained with the plants grown under water hyacinth mulch followed by other mulches such as straw, am-ada leaves and banana leaf while the control treatment gave the lowest values. Similar opinion was also put for worded by Buitellar (1989). Total dry matter per plant was measured at final harvest. Total dry matter (TDM) was also affected significantly by the water hyacinth mulch which produced the maximum $(89.63 \mathrm{~g})$ TDM followed by straw mulch while the minimum $(57.09 \mathrm{~g})$ TDM was obtained in control (Table 1).

Table 1. Effects of different mulching treatments on the growth of tomato

\begin{tabular}{lcccccccc}
\hline Treatment & $\begin{array}{c}\text { Plant } \\
\text { height }(\mathrm{cm})\end{array}$ & $\begin{array}{c}\text { No. of leaves } \\
\text { per plant }\end{array}$ & $\begin{array}{c}\text { Leaf area per } \\
\text { plant }\left(\mathrm{cm}^{2}\right)\end{array}$ & $\begin{array}{c}\text { Dry wt. of } \\
\text { leaves }(\mathrm{g})\end{array}$ & $\begin{array}{c}\text { Dry wt. of } \\
\text { stem }(\mathrm{g})\end{array}$ & $\begin{array}{c}\text { Dry wt. of } \\
\text { roots }(\mathrm{g})\end{array}$ & $\begin{array}{c}\text { Dry wt. of } \\
\text { fruits }(\mathrm{g})\end{array}$ & $\begin{array}{c}\text { Total dry } \\
\text { matter }(\mathrm{g})\end{array}$ \\
\hline Mo & 100.8 & 45.66 & 575.00 & 3.59 & 8.03 & 2.31 & 42.47 & 57.09 \\
$\mathrm{M}_{1}$ & 123.20 & 65.73 & 1007.00 & 4.95 & 9.79 & 3.39 & 70.31 & 89.63 \\
$\mathrm{M}_{2}$ & 115.80 & 60.59 & 795.60 & 4.66 & 9.48 & 3.11 & 51.26 & 69.70 \\
$\mathrm{M}_{3}$ & 112.20 & 56.15 & 671.50 & 4.45 & 9.29 & 2.72 & 47.91 & 65.02 \\
$\mathrm{M}_{4}$ & 104.10 & 53.24 & 610.60 & 4.06 & 9.10 & 2.47 & 50.20 & 65.51 \\
LSDa $_{0.05}$ & $3.169^{* *}$ & $2.22^{* *}$ & $49.10^{* *}$ & $0.35^{* *}$ & $0.95^{* *}$ & $0.20^{* *}$ & $4.210^{* *}$ & $5.11^{*}$ \\
\hline
\end{tabular}

$\mathrm{Mo}=$ Control, $\mathrm{M}_{1}=$ Water hyacinth, $\mathrm{M}_{2}=$ Straw, $\mathrm{M}_{3}=$ Am-ada leaf, $\mathrm{M}_{4}=$ Banana leaf

* indicate significant ${ }^{* *}$ indicate highly significant 
Plant height, number of leaves, and leaf area per plant showed significant variation due to different varieties. The tallest plant $(112.7 \mathrm{~cm})$, maximum number of leaves, and highest leaf area per plant were produced by Ratan followed by BARI tomato-3 except plant height. The varietal differences in respect to dry weight of leaves, stem, roots, and fruits per plant were highly significant. Ratan produced the highest dry weight of leaves, stem and roots except the dry weight of fruits per plant. While the lowest was produced in BARI tomato-3, the verities showed significant variation on the TDM. Ratan produced the highest TDM while the lowest was found in BARI tomato-3 (Table 2).

Table 2. Effects of different variety on the growth of tomato

\begin{tabular}{lcccccccc}
\hline Variety & $\begin{array}{c}\text { Plant height No. of leaves } \\
(\mathrm{cm})\end{array}$ & $\begin{array}{c}\text { Leaf area per plant } \\
\text { plant }\left(\mathrm{cm}^{2}\right)\end{array}$ & $\begin{array}{c}\text { Dry wt. of } \\
\text { leaves }(\mathrm{g})\end{array}$ & $\begin{array}{c}\text { Dry wt. } \\
\text { of stem }(\mathrm{g})\end{array}$ & $\begin{array}{c}\text { Dry wt. of } \\
\text { roots }(\mathrm{g})\end{array}$ & $\begin{array}{c}\text { Dry wt of } \\
\text { fruits }(\mathrm{g})\end{array}$ & $\begin{array}{c}\text { Total dry } \\
\text { matter }(\mathrm{g})\end{array}$ \\
\hline $\mathrm{V}_{1}$ & 109.5 & 57.16 & 716.20 & 3.70 & 7.98 & 2.34 & 50.13 & 66.17 \\
$\mathrm{~V}_{2}$ & 112.7 & 59.15 & 774.20 & 4.75 & 9.96 & 3.38 & 52.67 & 70.78 \\
$\mathrm{~V}_{3}$ & 111.4 & 52.50 & 705.7 & 4.57 & 9.48 & 2.68 & 54.48 & 71.22 \\
LSDa $_{0.05}$ & $2.455^{*}$ & $1.724^{*}$ & $38.04^{*}$ & $0.275^{\star *}$ & $0.739^{* *}$ & $0.155^{\star *}$ & $3.261^{* *}$ & $3.958^{*}$ \\
\hline
\end{tabular}

$\mathrm{V}_{1}=\mathrm{BARI}$ tomato-3, $\mathrm{V}_{2}=$ Ratan, $\mathrm{V}_{3}=$ BARI tomato- 6

* indicate significant ** indicate highly significant

The interaction between mulches and varieties had insignificant effect on plant height and number of leaves per plant and the significant effect on leaf area per plant. At harvest, the maximum plant height and number of leaves per plant were recorded from the treatment combination of water hyacinth mulch with Ratan. The maximum leaf area was obtained from the treatment combination of water hyacinth mulch with variety Ratan. Decoteau et al. (1989) reported that mulching significantly affected the growth of tomato compared to the control (no mulch). Water hyacinth mulch possibly conserved sufficient soil moisture that enhanced growth of Ratan producing the tallest plant and maximum number of leaves. The combination effect between mulching and variety on the dry weight of leaves, stem, roots and fruits per plant showed insignificant variation. The water hyacinth mulch with the variety Ratan produced the maximum dry weight of leaves, stem, roots and fruits per plant (Table 3). The combined effect of varieties and mulching on TDM was insignificant. The highest TDM $(92.37 \mathrm{~g})$ and lowest TDM $(55.59 \mathrm{~g})$ were found in the treatment combination of water hyacinth with Ratan and BARI tomato-3 having no mulch respectively (Table 3 ).

Table 3. Combined effects of mulching and variety on the growth of tomato

\begin{tabular}{|c|c|c|c|c|c|c|c|c|}
\hline $\begin{array}{c}\text { Variety } x \\
\text { Mulch }\end{array}$ & $\begin{array}{c}\text { Plant } \\
\text { height }(\mathrm{cm})\end{array}$ & $\begin{array}{c}\text { No. of leaves } \\
\text { per plant }\end{array}$ & $\begin{array}{l}\text { Leaf area per } \\
\text { plant }\left(\mathrm{cm}^{2}\right)\end{array}$ & $\begin{array}{l}\text { Dry wt. of } \\
\text { leaves }(\mathrm{g})\end{array}$ & $\begin{array}{c}\text { Dry wt. } \\
\text { of stem }(\mathrm{g})\end{array}$ & $\begin{array}{l}\text { Dry wt. of } \\
\text { roots }(\mathrm{g})\end{array}$ & $\begin{array}{l}\text { Dry wt. of } \\
\text { fruits }(\mathrm{g})\end{array}$ & $\begin{array}{c}\text { Total dry } \\
\text { matter }(\mathrm{g})\end{array}$ \\
\hline $\mathrm{V}_{1} \mathrm{M}_{0}$ & 98.32 & 45.14 & 583.20 & 3.20 & 6.92 & 2.15 & 41.30 & 55.59 \\
\hline $\mathrm{V}_{1} \mathrm{M}_{1}$ & 121.71 & 65.27 & 968.54 & 4.13 & 8.04 & 2.67 & 68.17 & 86.53 \\
\hline $\mathrm{V}_{1} \mathrm{M}_{2}$ & 113.56 & 61.72 & 796.83 & 3.89 & 7.92 & 2.43 & 48.41 & 66.23 \\
\hline$V_{1} M_{3}$ & 109.61 & 57.93 & 598.12 & 3.74 & 8.46 & 2.29 & 45.70 & 62.11 \\
\hline $\mathrm{V}_{1} \mathrm{M}_{4}$ & 104.52 & 55.76 & 694.58 & 3.56 & 8.56 & 2.18 & 47.09 & 60.39 \\
\hline $\mathrm{V}_{2} \mathrm{M}_{0}$ & 102.35 & 48.32 & 602.81 & 3.91 & 8.57 & 2.56 & 42.68 & 57.73 \\
\hline$V_{2} M_{1}$ & 124.53 & 69.31 & 1086.29 & 5.43 & 11.03 & 4.31 & 71.60 & 92.37 \\
\hline $\mathrm{V}_{2} \mathrm{M}_{2}$ & 118.60 & 63.73 & 861.37 & 5.16 & 10.72 & 3.93 & 52.32 & 72.13 \\
\hline $\mathrm{V}_{2} \mathrm{M}_{3}$ & 114.54 & 59.18 & 751.62 & 4.94 & 9.92 & 3.27 & 49.16 & 67.30 \\
\hline $\mathrm{V}_{2} \mathrm{M}_{4}$ & 103.60 & 55.23 & 699.57 & 4.35 & 9.58 & 2.86 & 47.60 & 64.39 \\
\hline $\mathrm{V}_{3} \mathrm{M}_{0}$ & 101.69 & 43.50 & 562.38 & 3.67 & 8.61 & 2.24 & 43.43 & 57.96 \\
\hline$V_{3} M_{1}$ & 123.40 & 62.61 & 809.65 & 5.31 & 10.32 & 3.21 & 71.16 & 90.00 \\
\hline $\mathrm{V}_{3} \mathrm{M}_{2}$ & 115.31 & 56.32 & 715.31 & 4.93 & 9.80 & 2.97 & 53.04 & 70.74 \\
\hline$V_{3} M_{3}$ & 112.50 & 51.35 & 604.89 & 4.67 & 9.51 & 2.62 & 48.86 & 65.66 \\
\hline $\mathrm{V}_{3} \mathrm{M}_{4}$ & 104.21 & 48.72 & 618.56 & 4.28 & 9.18 & 2.39 & 55.91 & 71.76 \\
\hline $\operatorname{LSDa}_{0.05}$ & NS & NS & $2.054^{*}$ & NS & NS & NS & NS & NS \\
\hline
\end{tabular}

$\mathrm{V}_{1}=\mathrm{BARI}$ tomato- $3, \mathrm{~V}_{2}=$ Ratan, $\mathrm{V}_{3}=$ BARI tomato- 6

$\mathrm{Mo}=$ Control, $\mathrm{M}_{1}=$ Water hyacinth, $\mathrm{M}_{2}=$ Straw, $\mathrm{M}_{3}=$ Am-ada leaf, $\mathrm{M}_{4}=$ Banana leaf

* indicates $5 \%$ level of significance, ${ }^{* *}$ indicates $1 \%$ level of significance, NS indicates in significance 
A significant variation in the number of flower clusters per plant, fruit per cluster and fruit per plant was observed in different mulching. Water hyacinth mulching produced the highest number of flower clusters per plant and number of fruits per plant followed by straw mulch (Table 4). The weight of individual fruit was highly significant by different mulches. The maximum individual fruit weight $(66.09 \mathrm{~g})$, fruit weight per plant $(1.50 \mathrm{~g})$, fruit weight per plot $(5.99 \mathrm{~g})$ and fruit yield $(59.94$ $\mathrm{t} / \mathrm{ha}$ ) was found with the plants grown under water hyacinth mulch followed by straw, am-ada leaf and banana leaf mulches, while the treatment without mulch showed the lowest performance.

Table 4. Effects of different mulching treatments on yield and yield components of tomato

\begin{tabular}{lccccccc}
\hline & $\begin{array}{c}\text { No. of flower } \\
\text { clusters per plant }\end{array}$ & $\begin{array}{c}\text { No. of fruit } \\
\text { per cluster }\end{array}$ & $\begin{array}{c}\text { No. of fruits } \\
\text { per plant }\end{array}$ & $\begin{array}{c}\text { Wt. of individual } \\
\text { fruit }(\mathrm{g})\end{array}$ & $\begin{array}{c}\text { Wt. of fruits } \\
\text { per plant }(\mathrm{kg})\end{array}$ & $\begin{array}{c}\text { Wt. of fruits } \\
\text { per plot }(\mathrm{kg})\end{array}$ & $\begin{array}{c}\text { Fruit yield } \\
(\mathrm{t} / \mathrm{ha})\end{array}$ \\
\hline $\mathrm{Mo}$ & 12.07 & 4.01 & 20.69 & 58.82 & 1.15 & 4.60 & 46.11 \\
$\mathrm{M}_{1}$ & 15.59 & 4.21 & 24.11 & 66.09 & 1.50 & 5.99 & 59.97 \\
$\mathrm{M}_{2}$ & 14.32 & 4.26 & 22.56 & 62.90 & 1.34 & 5.38 & 53.84 \\
$\mathrm{M}_{3}$ & 13.21 & 5.46 & 21.54 & 61.39 & 1.24 & 4.97 & 49.75 \\
$\mathrm{M}_{4}$ & 12.17 & 4.19 & 21.21 & 59.77 & 1.19 & 4.78 & 47.84 \\
$\mathrm{LSDa}_{0.05}$ & 0.619* & $0.591^{*}$ & $2.140^{*}$ & $4.636^{* *}$ & $0.027^{* *}$ & $0.249^{* *}$ & $4.813^{* *}$ \\
\hline
\end{tabular}

$\mathrm{Mo}=$ Control, $\mathrm{M}_{1}=$ Water hyacinth, $\mathrm{M}_{2}=$ Straw, $\mathrm{M}_{3}=\mathrm{Am}$-ada leaf, $\mathrm{M}_{4}=$ Banana leaf

${ }^{*}$ indicates $5 \%$ level of significance, ${ }^{* *}$ indicates $1 \%$ level of significance, $\mathrm{Wt}=$ Weight

The varieties showed significant variation amount the parameter studied. The highest number of flower cluster per plant, number of fruits per cluster and the number of fruits per plant was obtained from BARI tomato-3 followed by Ratan and BARI tomato-6 (Table 5). A marked variation in individual fruit weight was observed due to the influence of different varieties. BARI tomato-6 produced the highest fruit weight $(77.57 \mathrm{~g})$ followed by Ratan and BARI tomato-3. Mulching significantly influenced the varieties of tomato. The maximum weight of fruit $(1.34 \mathrm{~kg})$ per plant and fruit weight per plot $(5.37 \mathrm{~kg})$ was obtained from Ratan, which was statistically identical to BARI tomato-6. Bhangu and Singh (1993) observed that the variety punjab tropic produced the largest fruit $(66.69 \mathrm{~g})$ compared with other varieties. The highest yield $(53.74 \mathrm{t} / \mathrm{ha})$ was achieved from Ratan and the lowest yield 48.89t/ha was obtained from BARI tomato-3. Hossain (2001) observed that the variety BARI tomato-7 produced the highest fruit yield (57.02 t/ha) and the lowest (51.38 t/ha) in BARI tomato-5.

Table 5. Effects of variety on the yield and yield components of tomato

\begin{tabular}{lccccccc}
\hline Variety & $\begin{array}{c}\text { No. of flower } \\
\text { clusters per plant }\end{array}$ & $\begin{array}{c}\text { No. of fruit } \\
\text { per cluster }\end{array}$ & $\begin{array}{c}\text { No. of fruits } \\
\text { per plant }\end{array}$ & $\begin{array}{c}\text { Wt. of individual } \\
\text { fruit }(\mathrm{g})\end{array}$ & $\begin{array}{c}\text { Wt. of fruits } \\
\text { per plant (kg) }\end{array}$ & $\begin{array}{c}\text { Wt. of fruits } \\
\text { per plot }(\mathrm{kg})\end{array}$ & $\begin{array}{c}\text { Fruit yield } \\
(\mathrm{t} / \mathrm{ha})\end{array}$ \\
\hline $\mathrm{V}_{1}$ & 13.92 & 5.20 & 28.96 & 42.19 & 1.22 & 4.88 & 48.89 \\
$\mathrm{~V}_{2}$ & 13.87 & 4.18 & 20.43 & 65.62 & 1.34 & 5.37 & 53.74 \\
$\mathrm{~V}_{3}$ & 12.63 & 4.25 & 16.67 & 77.57 & 1.29 & 5.18 & 51.87 \\
$\mathrm{LSDa}_{0.05}$ & $0.479^{* *}$ & $0.458^{* *}$ & $1.658^{* *}$ & $3.591^{*}$ & $0.062^{*}$ & $0.193^{*}$ & $3^{*}$ \\
\hline
\end{tabular}

$\mathrm{V}_{1}=\mathrm{BARI}$ tomato-3, $\mathrm{V}_{2}=$ Ratan, $\mathrm{V}_{3}=\mathrm{BARI}$ tomato- 6

${ }^{*}$ indicates $5 \%$ level of significance, ${ }^{* *}$ indicates $1 \%$ level of significance

The combined effects between mulching and variety on number of fruits per cluster were found significant (Table 6). However, the highest number of fruits per cluster was found from BARI tomato-3 with am-ada mulch and the lowest from Ratan with straw mulch. The combined effects between mulching and variety on number of fruit per plant, weight of fruits per plant, weight of fruits per plot, individual fruit weight and yield per hectare were insignificant (Table 6). However, numerically the highest number of fruits per plant was found from the treatment combination of water hyacinth mulch with BARI tomato-3. Kumer et al. (1995) observed that mulching significantly increased the number of fruits per plant compared to the control. The maximum weight of individual fruit $(83.47 \mathrm{~g})$ was recorded from the treatment combination of water hyacinth mulch with BARI tomato-6. 
Table 6. Combined effects of mulching and variety on the yield and yield components of tomato

\begin{tabular}{|c|c|c|c|c|c|c|}
\hline $\begin{array}{l}\text { Variety } \mathrm{x} \\
\text { Mulch }\end{array}$ & $\begin{array}{l}\text { No. of fruit } \\
\text { per cluster }\end{array}$ & $\begin{array}{l}\text { No. of fruits } \\
\text { per plant }\end{array}$ & $\begin{array}{l}\text { Individual } \\
\text { fruit wt. (g) }\end{array}$ & $\begin{array}{l}\text { Wt. of fruits } \\
\text { per plant }(\mathrm{kg})\end{array}$ & $\begin{array}{l}\text { Wt. of fruits } \\
\text { per plot }(\mathrm{kg})\end{array}$ & $\begin{array}{l}\text { Yield } \\
\text { (t/ha) }\end{array}$ \\
\hline $\mathrm{V}_{1} \mathrm{Mo}$ & 4.43 & 27.42 & 39.33 & 1.087 & 4.34 & 43.54 \\
\hline $\mathrm{V}_{1} \mathrm{M}_{1}$ & 4.36 & 31.87 & 45.34 & 1.434 & 5.73 & 57.36 \\
\hline $\mathrm{V}_{1} \mathrm{M}_{2}$ & 5.62 & 29.05 & 43.12 & 1.525 & 5.00 & 50.08 \\
\hline $\mathrm{V}_{1} \mathrm{M}_{3}$ & 6.89 & 28.59 & 42.42 & 1.203 & 4.81 & 48.12 \\
\hline $\mathrm{V}_{1} \mathrm{M}_{4}$ & 4.71 & 27.88 & 40.71 & 1.134 & 4.53 & 45.36 \\
\hline $\mathrm{V}_{2} \mathrm{Mo}$ & 3.69 & 19.48 & 62.64 & 1.236 & 4.94 & 49.44 \\
\hline $\mathrm{V}_{2} \mathrm{M}_{1}$ & 4.75 & 22.37 & 69.70 & 1.554 & 6.21 & 62.16 \\
\hline $\mathrm{V}_{2} \mathrm{M}_{2}$ & 3.48 & 20.98 & 67.46 & 1.408 & 5.63 & 56.32 \\
\hline $\mathrm{V}_{2} \mathrm{M}_{3}$ & 4.97 & 19.68 & 65.35 & 1.279 & 5.11 & 51.16 \\
\hline $\mathrm{V}_{2} \mathrm{M}_{4}$ & 4.02 & 19.65 & 63.18 & 1.241 & 4.96 & 49.64 \\
\hline $\mathrm{V}_{3} \mathrm{Mo}$ & 3.92 & 15.17 & 74.47 & 1.134 & 4.53 & 45.36 \\
\hline $\mathrm{V}_{3} \mathrm{M}_{1}$ & 3.53 & 18.10 & 83.47 & 1.513 & 6.04 & 60.40 \\
\hline $\mathrm{V}_{3} \mathrm{M}_{2}$ & 3.71 & 17.65 & 78.11 & 1.378 & 5.51 & 55.12 \\
\hline $\mathrm{V}_{3} \mathrm{M}_{3}$ & 4.52 & 16.36 & 76.39 & 1.249 & 4.99 & 49.96 \\
\hline $\mathrm{V}_{3} \mathrm{M}_{4}$ & 3.86 & 16.09 & 75.41 & 1.213 & 4.85 & 48.52 \\
\hline $\operatorname{LSDa}_{0.05}$ & $1.024^{*}$ & NS & NS & NS & NS & NS \\
\hline
\end{tabular}

$\mathrm{V}_{1}=\mathrm{BARI}$ tomato-3, $\mathrm{V}_{2}=$ Ratan, $\mathrm{V}_{3}=\mathrm{BARI}$ tomato- 6 , Wt. $=$ Weight

$\mathrm{Mo}=$ Control, $\mathrm{M}_{1}=$ Water hyacinth, $\mathrm{M}_{2}=$ Straw, $\mathrm{M}_{3}=\mathrm{Am}$-ada leaf, $\mathrm{M}_{4}=$ Banana leaf

${ }^{*}$ indicates $5 \%$ level of significance, ${ }^{* *}$ indicates $1 \%$ level of significance, NS indicates in significance

The maximum weight of fruit per plant and the highest yield per hectare were recorded from the treatment combination of water hyacinth mulch with Ratan. Water hyacinth mulch conserved sufficient soil moisture and maintained higher temperature which might be responsible for increased plant growth and development in Ratan, which ultimately increased yield. Singh et al. (1987) reported that mulching by paddy straw decreased soil water depletion and increased water uses efficiency. The highest weight of fruits per plot was obtained from the treatment combination of water hyacinth with Ratan. Streck et al. (1995) also reported that soil temperature and yield were generally higher under mulched condition. The maximum weight of individual fruit was recorded from the treatment combination of water hyacinth with BARI tomato- 6 .

\section{CONCLUSION}

It is concluded from this study that water hyacinth and straw mulches have potentiality to increase the yield of tomato under Bangladesh content, which involves minimum cost of production. Farmers of Bangladesh may use those mulches which might increase the total production per unit area of land.

\section{LITERATURE CITED}

Bhangu, J. S. and S. Singh. 1993. Comparative performance of tomato cultivars under rainfed conditions of Kandi area (Panjab). Panjab Hort J 33(1/4), 123-126.

Buitellar, K. 1989. [Substance Red reflective film? Just forget it] Subtract Rode reflective Virgate Wit mar. Groentenen Fruit 45(17), 41 [Cited from Hort Abstr 60(5), 3467 (1990)].

Decoteau, D. R. Bauer, M. J. K. and Hunt, P. G. 1989. Mulch surface colour affects yield of freshmarket tomatoes. J Amer Soc Hort Sci 114(2), 216-219.

Gomez, K. A. and Gomez, A. A. 1984. "Statistical Procedure for Agricultural Research" (Second Edn.). John Willey and Sons, New York. 680 pp.

Hossain, M. M. 2001. Influence of planting time on the extension of picking period of four tomato varieties. Unpublished [MS Thesis], Department of Horticulture, Bangladesh Agricultural University Mymensingh. 46 pp. 


\section{A. Kayum et al.}

Kumer, V., Bishnoi, O. P., Rao, V. U. M., Singh, D. and Singh, S. 1995. Biomass production in summer moong under various mulching treatments. Indian J Plant Physiol 38(1), 94-96.

Lal, R. 1989. Conservation tillage for sustainable Agriculture: Tropic versus temperate environments. Adv Agron 42, 147-151.

Patil, A. V. and Basad, A. D. 1972. Effect of mulching treatment on soil properties, growth and yield of tomato (var. Siouk). Indian J Hort 29(2), 197-205.

Singh, P. N., Joshi B. P. and Singh G. 1987. Effect of mulch on moisture conservation, irrigation requirement and yield of potato. Indian J Agron 32(4), 451-452.

Streck, N. A., Schneider F. M., Buriol, G. A. and Heldwein, A. B. 1995. Effect of polythene mulches on soil temperature and tomato yield in a plastic green house. Scientia Agricola 52(2), 587593.

Suh, J. K. and Kim, Y. S. 1991. Studies of improvement of mulching, cultivar and method in onion. Res Rep Rural Dev Adm Hort 33(3), 31-36. 